\title{
Views of emergency physicians working in university and state hospitals in Turkey regarding the use of analgesics in patients with acute abdominal pain
}

\author{
Özgür Özen, M.D., Selahattin Kıyan, M.D.
}

Department of Emergency Medicine, Ege University Faculty of Medicine Hospital, İzmir-Turkey

\begin{abstract}
BACKGROUND: Use of narcotic analgesics in patients with acute abdominal pain does not cause delayed misdiagnosis, increases patient comfort and does not suppresses physical examination. The purpose of this study was to determine attitudes anddaily practices of emergency medicine (EM) specialists, residents and faculty members in Turkey on the use of analgesics in patients with acute abdominal pain and factors affecting their decisions on the use of analgesics.
\end{abstract}

METHODS: A cross-sectional study was performed between November 15, 2013 and January 25, 2014 by conducting a questionnaire to EM physicians working in University Hospitals, Education and Research Hospitals of the Ministry of Health, State Hospitals, and Private Hospitals in Turkey.

RESULTS: A total of 803 questionnaires (participation rate: $47 \%$ ) were completed. $59.3 \%(n=470)$ of the participants were research assistants. $49.5 \%$ of the participants reported that analgesic drugs "suppressed" physical examination findings. They stated that $90 \%$ of the patients "always" and "often" requested analgesics and that $34.6 \%$ of surgery consultant physicians "rarely" recommended the use of analgesics, while $28.7 \%$ "never" recommended, and that there was no common policy established together with surgical departments (79.1\%). According to the comparison between the EM specialists and residents, residents in the group stating that they would "never" use analgesics were higher than specialists in number $(p=0.002)$; residents reported that they administered analgesics "upon surgical intervention decision", while specialists reported that they administered analgesics "after patient's examination and treatment plan" ( $p=0.021)$; residents reported that analgesics "suppressed" physical examination findings, while specialists reported that analgesics "clarified" physical examination findings $(p<0.0001)$; residents reported that they did not administer analgesics "before examination by surgeon", while specialists reported otherwise $(p=0.0001)$. Senior residents $(>24$ months) reported that they administered analgesics "often" compared to junior residents $(p=0.034)$ and that junior residents believed that the use of analgesics would "suppress physical examination findings" at a higher percentage $(p=0.002)$.

CONCLUSION: The rates of use of analgesics in patients with acute abdominal pain by EM physicians are very low. The rates of use of analgesics by EM residents are much lower compared to EM specialists, and they highly believe that analgesic drugs suppress physical examination findings. Residents tend to administer analgesic drugs at a later stage. As seniority of residents increases, the rate of analgesics use and the opinion that analgesic drugs have no effect on physical examination findings increases.

Keywords: Abdominal pain; analgesics; emergency physicians; survey.

Address for correspondence: Selahattin Kıyan, M.D.

Ege Üniversitesi Tıp Fakültesi Hastanesi, Acil Tıp Anabilim Dalı, 35100 İzmir, Turkey

Tel: +90 232 - 3902326 E-mail: selahattin.kiyan@ege.edu.tr

Qucik Response Code

Ulus Travma Acil Cerrahi Derg

2016;22(2): 175-183

doi: $10.5505 /$ tjtes.20I5.06706

Copyright 2016

TJTES

\section{INTRODUCTION}

The concern in the general surgery practice that the use of analgesics for patients with acute abdominal pain without establishing a final diagnosis will change physical examination findings is rather high. ${ }^{[l]}$ It was underlined that analgesics would alter physical examination findings, suppress progression of symptoms, affect accuracy of diagnosis, and increase time to establish diagnosis. ${ }^{[1]}$ However, surgical ${ }^{[2-4]}$ and EM studi$\mathrm{es}^{[5-11]}$ conducted in the last two decades have completely changed this opinion. Finally, this was clearly set forth in the 
ACEP (American College of Emergency Medicine) clinical policy ${ }^{[2]}$ in 2010 and in the Cochrane review in 2011 (there are sufficient data in this review to suggest that the use of opioid analgesics in patients with AAP does not increase the risk of inadequate treatment decisions; and indeed, it significantly improves the patient's comfort level while the diagnostic process is brought to a conclusion). ${ }^{[13]}$ The use of narcotic analgesics has also become recommendable in classic surgery textbooks. ${ }^{[14]}$

Apart from a similar survey study carried out again by us in our country in $2006,{ }^{[15]}$ there is no study conducted on the frequency of use of analgesics in patients with acute abdominal pain by EM and general surgery departments and factors affecting the use of analgesics by physicians. Moreover, there is no consensus or algorithm established between these departments in the subject matter. With this study, we intended to cover a wider study population (322 versus 803 participants) and all work places of EM physicians (university hospitals versus state hospitals, private hospitals, education and research hospitals and universities) and determine attitudes of EM physicians towards the use of analgesics, their daily practices, factors affecting the decision to use analgesics and understand changes in behaviours and causes for these changes unlike the similar study we conducted in 2006.

\section{MATERIALS AND METHODS}

This cross-sectional study was conducted between November 15, 2013 and January 25, 2014 after obtaining the approval of the ethics committee of Ege University Faculty of Medicine. The study was performed conducting a questionnaire on EM physicians (EM residents, specialists and faculty members) working in University Hospitals, Education and Research Hospitals of the Ministry of Health, state hospitals and private hospitals in Turkey.

\section{Data Collection}

The questionnaires were conducted via the web-address (https:// docs.google.com/forms/d/Ia6nTje_WxjWW260oB2Q AG8PzIzFxhmmo T_X-OEtc0Sk/viewform) and e-mail. Those who did not respond were e-mailed two more times and reached out through their mobile phones.

Participants were asked about their socio-demographic characteristics, organizations of employment and types of positions in the first chapter of the questionnaire form. In the second chapter, a total of 25 survey questions were asked. Seven out of these questions were about practices and attitudes of physicians on the administration of analgesics (frequency, time of administration of analgesic, demand by patients for analgesics, frequency of administration of analgesics without examination by surgeons or without definitive diagnosis, drug preferences and maintaining pain control). Four out of these questions were about opinions and joint follow-up patient strategies of surgeons whom emergency physicians worked together. Fourteen questions in the questionnaire consisted of questions regarding the opinions of emergency physicians on the use of analgesics (reasons for supporting or not supporting the administration of analgesics, whether or not age, gender, educational status, nature, region, severity of pain, physical examination, laboratory findings and final diagnosis of patients were effective).

Data was analysed by a statistical package program. For descriptive analysis; mean, standard deviation and frequency tables were used. For further analysis, Chi-Square and Student's $t$ Test and ANOVA were used. $p<0.05$ was accepted as significant (Cl: 95\%).

\section{RESULTS}

According to the data of the personnel department of the Ministry of Health and EM profession societies as of 2014, fifty-seven academic emergency departments of university hospitals and 39 Education and Research Hospitals of the Ministry of Health provide emergency medical training in emergency clinics. As of the date we conducted our study, the total number of EM specialists was 708 (57 in university hospitals, 37 in private hospitals and 614 state-education-research hospitals), including II EM professors, 79 EM associates (I8 in education-research hospitals, $6 \mathrm{I}$ in university hospitals), and the total number of EM residents was 1002 (482 in education-research hospitals, 520 in university hospitals). A total of 803 questionnaires (participation rate: $47 \%$ ) were completed through internet connection $(n=410)$ and e-mail $(n=393)$.

\section{Socio-Demographic Data}

Organizations of employment of participants were $48.3 \%$ education and research hospitals $(n=355), 40.5 \%$ university hospitals $(n=298)$, and II.2\% state hospitals $(n=82)$, respectively. $59.3 \%(n=470)$ of the participants were research assistants, $35.1 \%(n=278)$ were emergency medicine specialists, and $5.7 \%(n=45)$ of the emergency medicine specialists were faculty members in university and education and research hospitals.

\section{Practices, Attitudes and Opinions of EM Physicians on the Use of Analgesics}

When the participants were asked how the use of analgesics affected physical examination findings, the answers given by the participants were; "suppressed" in 49.5\% ( $n=395)$, "did not affect"'in 45.9\% $(n=366)$, and "clarified" in $4.6 \%(n=37)$, respectively. When the participants were asked about the frequency of use of analgesics, 34.5\% ( $n=276)$ of the participants stated that they used analgesics "often", 32.3\% ( $n=259)$, 'sometimes', 6\% ( $n=50)$ "always", and 4.9\% "never”. When the participants were asked about the time of use of analgesics, it was observed that $50.7 \%(n=393)$ of the participants reported that they administered analgesics "After Patient's Exami- 
nation and Treatment Plan", 16.6\% $(n=129)$ "upon exclusion of surgical intervention", 16.4\% ( $n=127)$ "After Diagnosis", $14.5 \%(n=1 \mid 2)$ "after examination by surgeon", and I.8\% $(n=14)$ "upon surgical intervention decision". When the participants were asked about the administration of analgesics before examination by a general surgeon, $60.6 \%(n=487)$ of the participants gave the answer "I do administer" and it was observed that $56.9 \%(n=457)$ of the participants reported that they used analgesics. When the participants were asked about the frequency of requests for analgesics by patients, $47.9 \%$ $(n=383)$ of the participants reported that patients "always" requested analgesics, while $41.6 \%(n=333)$ reported "often".

Reasons of the participants for supporting and not supporting the use of analgesics are given in Table I.

When the participants were asked about the analgesics they used, $60.8 \%(n=488)$ of the participants reported that they used fentanyl, 32.8\% ( $n=263)$ spasmolytic, $26 \% \quad(n=209)$ morphine, 19.9\% $(n=160)$ paracetamol, $18.7 \%(n=150)$ NSAIDs (non-steroidal anti-inflammatory drugs), $17.8 \%(n=143)$ meperidine, and $16.4 \%(n=132)$ tradamol, respectively.

When the participants were asked about the frequency of recommendation of analgesics by surgery consultant physicians, it was determined that $34.6 \%(n=272)$ of the participants answered "rarely", 28.7\% ( $n=225)$ "never", and 24.4\% $(n=196)$ "sometimes". When it was asked to the participants whether they had a common policy established with surgical departments, $79.1 \%(n=628)$ of the participants answered they did not, while $11.3 \%(n=90)$ answered they had.
When the participants were asked about the factors affecting their decisions on administering analgesics pre-general surgery consultation and the levels of importance of these factors, $45.9 \%(n=358)$ of the participants reported that "degree of severity of patient's pain" was very important, while $26.8 \%$ $(n=208)$ of the participants reported "time elapsed for surgical consultation" was very important; and these answers were followed by "concern for the alteration of physical examination" by $22.4 \%(n=174)$, "concern for diagnostic accuracy" by $17.5 \%(n=136)$, and "concern for disagreement with consultant physician" by $9.5 \%(n=73)$.

When the participants' opinions on patient-related factors were examined (Table 2), it was found out that the use of analgesics by the participants was largely supported if the patient had a colic, severe pain only in terms of the pain characteristics, had normal physical examination findings only in terms of the physical examination findings, had an abdominal tomography within normal limits only in terms of the radiological examinations and if the patient's diagnosis was established (independently of diagnosis, in the diagnosis of renal colic the most frequently);however, patient's age, gender, socio-cultural level, and laboratory findings did not affect their decision to use analgesics.

\section{Academic Hierarchy and Decisions on the Use of Analgesics by Institutions}

\section{a. Comparison of EM specialists (State vs. University Hospitals)}

No statistically significant difference was found when EM specialists and faculty were compared in terms of the frequency

Table I. Distribution of the reasons of emergency physicians for supporting and not supporting the use of analgesics in patients with acute abdominal pain

Your reasons to support the use of analgesics

It does not affect physical examination findings

It is unethical to monitor patients when they are suffering from pain

It increases not only patients' comfort, but also physicians' comfort

The literature supports that analgesics are safe

It is the patient's right to ask for relief of his/her pain

It accelerates the process of establishing diagnosis

Your reasons no to support the use of analgesics

It suppresses physical examination findings

It causes delay in accurate diagnosis of the patient

It may lead to disagreements with surgery consultant physicians

Evidence in the literature is not sufficient to support that analgesics are safe

It causes misdiagnosis

The pain suffered should be endured until diagnosis is established

I do hold off from administering analgesics because they may lead to complications 
Table 2. Distribution of patient-related factors in deciding the use of analgesics

\begin{tabular}{|c|c|c|c|}
\hline Factors & Disagree (\%) & Uncertain (\%) & Agree (\%) \\
\hline \multicolumn{4}{|l|}{ Age } \\
\hline I use analgesics if the patient is young & 52.7 & 15.4 & 31.9 \\
\hline I use analgesics if the patient is elderly & 58.6 & 17.6 & 23.8 \\
\hline \multicolumn{4}{|l|}{ Gender } \\
\hline I use analgesics if the patient is male & 60.1 & 14.5 & 25.3 \\
\hline I use analgesics if the patient is female & 61.2 & 15.0 & 23.7 \\
\hline \multicolumn{4}{|l|}{ Socio-cultural structure } \\
\hline I use analgesics if the patient has a high socio-cultural level & 57.1 & 13.9 & 29.0 \\
\hline I use analgesics if the patient has a low socio-cultural level & 61.2 & 15.0 & 23.9 \\
\hline \multicolumn{4}{|l|}{ Features of pain } \\
\hline I use analgesics if the pain is colic & 23.1 & 13.8 & 63.1 \\
\hline \multicolumn{4}{|l|}{ I use analgesics if the patient has a previous history of admission } \\
\hline to emergency department for similar pain reasons & 31.5 & 19.5 & 49.0 \\
\hline I use analgesics if the pain is severe & 28.7 & 16.3 & 55.0 \\
\hline I use analgesics if the pain is blunt & 42.8 & 21.3 & 35.8 \\
\hline I use analgesics if the pain is bearable & 57.9 & 20.3 & 21.8 \\
\hline \multicolumn{4}{|l|}{ Physical examination findings } \\
\hline I use analgesics if abdominal examination findings are typical & 19.1 & 14 & 66.9 \\
\hline I use analgesics only if there is a sensitivity in upper left quadrant & 43.6 & 17.8 & 38.6 \\
\hline I use analgesics only if there is a sensitivity in upper right quadrant & 45.1 & 15.7 & 39.2 \\
\hline I use analgesics only if there is a sensitivity in lower left quadrant & 47.6 & 17.2 & 35.3 \\
\hline I use analgesics if there a defence or rebound is found during the examination & 47.1 & 18.4 & 34.5 \\
\hline I use analgesics only if there is a sensitivity in lower right quadrant & 63.4 & 15.0 & 21.6 \\
\hline I use analgesics only if there is a sensitivity in periumbilical region & 55.9 & 17.1 & 27.1 \\
\hline I use analgesics if the patient does not have fever & 57.1 & 14.6 & 28.3 \\
\hline I use analgesics if the patient has fever & 56.3 & 15.5 & 28.2 \\
\hline \multicolumn{4}{|l|}{ Laboratory findings } \\
\hline I use analgesics if there is no leucocytosis followed by the pain & 46.8 & 19.2 & 34.0 \\
\hline I use analgesics if there is leucocytosis followed by the pain & 60.9 & 15.7 & 23.4 \\
\hline \multicolumn{4}{|l|}{ Radiologic findings } \\
\hline I use analgesics if the patient's abdominal tomography results are normal & 20.2 & 19.7 & 60.2 \\
\hline I use analgesics if the patient's abdominal ultrasound results are normal & 35.0 & 25.9 & 39.0 \\
\hline I use analgesics if the patient's upright abdominal $X$-ray results are normal & 53.4 & 18.0 & 28.6 \\
\hline \multicolumn{4}{|l|}{ Diagnostıc approach } \\
\hline I use analgesics if the diagnosis is established & 11.7 & 8.9 & 79.4 \\
\hline I use analgesics if the patient is diagnosed with acute cholecystitis & 10.2 & 9.4 & 80.4 \\
\hline I use analgesics if the patient is diagnosed with acute pancreatitis & 10.4 & 9.7 & 79.9 \\
\hline I use analgesics if the patient is diagnosed with acute appendicitis & 17.7 & 11.8 & 70.5 \\
\hline I use analgesics if the patient is diagnosed with acute gastroenteritis & 15.7 & 15.1 & 69.2 \\
\hline I use analgesics if the patient is diagnosed with acute mesenteric ischaemia & 16.6 & 17.5 & 65.8 \\
\hline I use analgesics if the patient is diagnosed with ileus & 26.8 & 15.7 & 57.5 \\
\hline I use analgesics if the patient is diagnosed with renal colic & 6.7 & 5.7 & 87.6 \\
\hline I use analgesics if the diagnosis is not clear & 47.6 & 22.3 & 30.1 \\
\hline
\end{tabular}

of use of analgesics, medication times, effects on physical examination findings, administration before examination of patient by surgical consultant specialist reasons for suppor- ting and not supporting the use of analgesics before definitive diagnosis, and the effect of patient-related factors on the use of analgesics. 


\section{b. Comparison of EM specialists (state-university) and residents}

When the frequency of use of analgesics was examined, while there was no difference between those stating that they would use analgesics "often" and "always", the number of residents who sated that they would "never" use was statistically greater and significant compared to the specialist physicians (Chi-square: 17.484, $p=0.002$ ) (Table 3). According to the time of analgesics administration, residents reported that they administered analgesics "'upon surgical intervention decision", while specialist physicians reported that they administered analgesics "after patient's examination and treatment plan" (Chi-square: II .595, p=0.02I) (Table 4). When the participants were asked about the effect of the use of analgesics on physical examination findings, residents reported that analgesics "suppressed" physical examination findings, while specialists physicians reported that analgesics "clarified" the findings (Chi-square: $31.760, p<0.0001$ ) (Table 5). About the administration of analgesics before examination by surgeon, residents $(71.1 \%, n=219)$ reported that they would not administer analgesics "before examination by surgeon", while spe- cialist physicians $(48.2 \%, \mathrm{n}=234$ ) reported otherwise (Fisher's Exact $p=0.0001$ ). The most common reasons stated by the residents, among the reasons for not supporting the use of analgesics are given Table 6 . When the analgesics used were examined, it was figured out that both residents and specialist physicians used narcotic analgesics the most, and it was observed that the rates of use of NSAIDs were also higher in the two groups ( $\mathrm{n}=80$ residents, $\mathrm{n}=66$ specialist physicians).

\section{c. Comparison of EM residents employed in State Hospitals to University Hospitals}

When the frequency of use of analgesics was examined, the number of those who reported that they would "never" and "rarely" use analgesics $(21.2 \%, n=91)$ was statistically greater and significant than those employed in university hospitals $(9.3 \%, n=40)$, while there was no difference between those who reported that they would use analgesics "often and "always" (Chi-square: $18.719 \mathrm{p}=0.001$ ). No difference was found between the two groups in terms of answers given about the effect of use of analgesics on physical examination findings. The two groups gave the answer that

Table 3. Comparison of emergency medicine specialists (state-university) and emergency medicine residents by the frequency of use of analgesics

\begin{tabular}{|c|c|c|c|c|c|}
\hline \multirow[t]{2}{*}{ Frequency of use of analgesics } & \multicolumn{2}{|c|}{$\begin{array}{l}\text { Emergency medicine } \\
\text { resident }\end{array}$} & \multicolumn{2}{|c|}{$\begin{array}{c}\text { Emergency medicine } \\
\text { specialist }\end{array}$} & \multirow{2}{*}{$\begin{array}{c}\text { Total } \\
\text { n }\end{array}$} \\
\hline & $\mathbf{n}$ & $\%$ & $\mathbf{n}$ & $\%$ & \\
\hline Never & 24 & 61.5 & 15 & 38.5 & 39 \\
\hline Rarely & 126 & 71.6 & 50 & 28.4 & 176 \\
\hline Sometimes & 147 & 57.9 & 107 & 42.1 & 254 \\
\hline Often & 149 & 54.6 & 124 & 45.4 & 273 \\
\hline Always & 23 & 46 & 27 & 54 & 50 \\
\hline Total & 469 & 59.2 & 323 & 40.8 & 792 \\
\hline
\end{tabular}

Chi-square: $17.484 ; p=0.002$.

Table 4. Comparison of emergency medicine specialists (state-university) and emergency medicine residents by time of administering analgesic drugs

\begin{tabular}{|c|c|c|c|c|c|}
\hline \multirow[t]{2}{*}{ Time of administering analgesic drugs } & \multicolumn{2}{|c|}{$\begin{array}{l}\text { Emergency medicine } \\
\text { resident }\end{array}$} & \multicolumn{2}{|c|}{$\begin{array}{c}\text { Emergency medicine } \\
\text { specialist }\end{array}$} & \multirow{2}{*}{$\begin{array}{c}\text { Total } \\
\text { n }\end{array}$} \\
\hline & $\mathbf{n}$ & $\%$ & $\mathbf{n}$ & $\%$ & \\
\hline After examination, plan & 210 & 53.6 & 182 & 46.4 & 392 \\
\hline After examination by surgeon consultant & 68 & 61.8 & 42 & 38.2 & 110 \\
\hline When surgical intervention is excluded & 77 & 61.6 & 48 & 38.4 & 125 \\
\hline After diagnosis & 84 & 67.7 & 40 & 32.3 & 124 \\
\hline When decision for surgery is made & II & 78.6 & 3 & 21.4 & 14 \\
\hline Total & 431 & 58.8 & 285 & 41.2 & 716 \\
\hline
\end{tabular}

Chi-square: $11.595 ; p=0.021$. 
Table 5. Comparison of opinions of emergency medicine specialists (state-university) and emergency medicine residents regarding the effects of use of analgesics on physical examination findings

\begin{tabular}{|c|c|c|c|c|c|}
\hline \multirow[t]{2}{*}{ Effects on physical examination findings } & \multicolumn{2}{|c|}{$\begin{array}{l}\text { Emergency medicine } \\
\text { resident }\end{array}$} & \multicolumn{2}{|c|}{$\begin{array}{l}\text { Emergency medicine } \\
\text { specialist }\end{array}$} & \multirow{2}{*}{$\begin{array}{c}\text { Total } \\
\text { n }\end{array}$} \\
\hline & $\mathbf{n}$ & $\%$ & $\mathbf{n}$ & $\%$ & \\
\hline Suppressing & 271 & 69.5 & 119 & 30.5 & 390 \\
\hline Clarifying & 17 & 45.9 & 20 & 54.1 & 37 \\
\hline No effect & 182 & 50.3 & 180 & 49.7 & 362 \\
\hline Total & 470 & 59.6 & 319 & 40.4 & 789 \\
\hline
\end{tabular}

Chi-square: $31.760 ; p<0.0001$.

Table 6. Comparison of emergency medicine specialists (state-university) and emergency medicine residents by reasons for not supporting the use of analgesics

\begin{tabular}{|c|c|c|c|c|c|}
\hline \multirow[t]{2}{*}{ Reasons for not supporting } & \multicolumn{2}{|c|}{$\begin{array}{l}\text { Emergency medicine } \\
\text { resident }\end{array}$} & \multicolumn{2}{|c|}{$\begin{array}{c}\text { Emergency medicine } \\
\text { specialist }\end{array}$} & \multirow{2}{*}{$\begin{array}{c}\text { Total } \\
\text { n }\end{array}$} \\
\hline & $\mathbf{n}$ & $\%$ & $\mathbf{n}$ & $\%$ & \\
\hline It represses physical examination findings & 82 & 71.9 & 32 & 28.1 & 114 \\
\hline It causes delays in accurate diagnosis of the patient & 46 & 83.6 & 9 & 16.4 & 55 \\
\hline The patient should bear the pain until his/her diagnosis is established & 5 & 62.5 & 3 & 37.5 & 8 \\
\hline There is no supporting data in the literature & 18 & 72.0 & 7 & 28.0 & 25 \\
\hline $\mathrm{He} /$ she fears some complications that are likely to emerge & 4 & 66.7 & 2 & 33.3 & 6 \\
\hline It causes misdiagnosis & 20 & 80 & 5 & 20 & 25 \\
\hline He/she has concerns about disagreements with surgery consultant physician & 20 & 57.1 & 15 & 42.9 & 35 \\
\hline Total & 195 & 72 & 73 & 28 & 268 \\
\hline
\end{tabular}

Chi-square: $16.461 ; p=0.021$.

analgesics would suppress physical examination findings at the rate of $57 \%$.

\section{d. Comparison of EM residents by their seniority (un- der and over 24 months)}

When the frequency of use of analgesics was examined, a statistical difference was found between the two groups, and it was observed that this difference resulted from the fact that senior residents (>24 months) administered analgesics "often" compared to junior residents (40\% versus $27 \%$ ) (Chisquare: 10.434, $p=0.034)$. A statistical difference was also found in answers for the effect of use of analgesics on physical examination findings, and it was observed that this difference resulted from the answer given by junior residents that use of analgesics would "suppress physical examination findings" (68\% versus $40 \%$ ) (Chi-square: $12.683, p=0.002$ ).

\section{DISCUSSION}

It was found out in our study that the frequency of use of analgesics by EM physicians in Turkey was relatively low and half of physicians still believed that analgesics "suppressed physical examination findings". It was observed that general surgeons did not recommend the use of analgesics in many hospitals, and there was no consensus or algorithms established to date between the two departments. EM residents used less analgesics than EM specialists, but administered them "upon surgical intervention decision", did not administer them "before examination by general surgeon", and believed that the use of analgesics "suppressed physical examination findings". Thoughts in relation to that analgesics suppressed physical examination findings decreased as seniority of the residents increased, and analgesics were used more often.

Our study was the continuation of the study we conducted in 2006. ${ }^{[5]}$ Fifty four percent of the emergency physicians in our study in $\mathbf{2 0 0 6}$ had reported that the use of analgesics "suppressed physical examination findings". Thirty five percent of them had reported that they administered analgesics "after patient's examination and treatment plan" while $32 \%$ of them had reported that they administered "before examination by general surgeon", and the most important factor in deciding to 
administer analgesics was "patient's degree of pain" and "time elapsed for examination of patient by surgical consultant". It was observed in the current study that opinions of physicians regarding that the use of analgesics suppressed physical examination findings, and the most important factors in deciding to administer analgesics had not changed, but physicians using analgesics administered analgesics "independent of surgeon" at a higher rate $(60 \%)$ and "after patient's treatment plan" (50\%) and "before definitive diagnosis" (60\%).

Although evidence in the literature supports and it is included in surgery and EM textbooks, what might the reasons be for EM physicians to hesitate using analgesics? First of all, this subject is not sufficiently explained to residents during annual training programs, adequate theoretical training about the subject matter is not delivered and it is not emphasized during point-of-care training in daily practice. The fact that residents reported that they used analgesics less compared to specialists and believed that the use of analgesics would suppress physical examination findings and also the rates of residents to use analgesics increased as their seniority increased in our study supports our hypothesis.

Concern for disagreement with surgeon and that surgeons strictly do not recommend administration of analgesics to patients may be another reason. Practices of EM residents in administering analgesics to patients "upon surgical intervention decision" and "after examination by surgeon" also support our hypothesis. EM residents may not receive sufficient support from their specialists and trainers in patient follow-up and may stay alone with surgeons. This situation may cause EM residents to remain undecided to administer analgesics to patients because they cannot receive support from EM specialists. Fear of misdiagnosis, delayed diagnosis, hesitation from malpractice especially in our country has increased significantly in the recent years due to lawsuits filed against physicians. When fear of harming patients is added to these drawbacks, it may seem more preferable to EM physicians to decide on "not to make a decision independent of surgeon" and"not to administer analgesics until surgery".

Administering analgesics to patients may also be delayed in teaching hospitals because of the hierarchical system of most surgical programs. Often a surgical intern and then a junior staff member are sent to evaluate emergency patients before speaking with the surgical senior or the attending physician. These examinations may be quite time consuming. ${ }^{[15]}$ When patients do not receive analgesia in the ED, the first dose of pain medication is delayed at an average of 5.7 hours. This delay is often attributed to junior staff hesitation in administering medication due to the concern of possibly masking important symptoms. ${ }^{[16]}$

The fact that EM physicians did not use analgesics although they reported that approximately $90 \%$ of the patients requested for analgesics "always" and "frequently" is anot- her striking finding. Article II of the regulation on patients' rights ${ }^{[17]}$ states that "Patients have the right to be diagnosed, to be treated and claim to be cared in accordance with the requirements of the current medical knowledge and technology", and Article I4 states that "it is necessary to endeavour to reduce or relieve patient's pain". It should be remembered that patient's pain and suffering can be subject to a separate complaint and lawsuit on the ground that EM physicians and surgeons fail to administer a literature-proved treatment which must be used due to "fear of misdiagnosis, delayed diagnosis, harming patients and fear of malpractice".

In the literature, studies have assessed the factors effective in the decision-making process regarding how to deal with the pain of the patients regarding their ages, sexes, languages, cultural and ethnic differences, moral values, life styles, and habits. ${ }^{[16,18-23]}$ The previous study discovered that physical examination, laboratory findings, nature and severity of pain and final diagnosis affected decisions of EM physicians in addition to these factors. This current study showed that these factors did not affect the decision of use of analgesics for EM physicians. Based on our findings, it seems logical to think that physicians supporting the use of analgesics have administered analgesics independently of these factors and those not supporting the use of analgesics have not administered analgesics independently of these factors.

It was found out in this study that EM physicians used narcotic analgesics the most at similar rates compared to the previous study. It is striking that physicians reported the use of NSAIDs at the rates (20 \& 23\%) similar to the previous study. Narcotic analgesics are used for abdominal analgesia. It is particularly emphasized that NSAID drugs should not be used. ${ }^{[13]}$ Although the reason for such significantly high use cannot be fully understood, it may be a reason that EM physicians administer NSAIDs to patients who will undergo surgery, who are established a final diagnosis or who do not require surgery and will be followed up (cholecystitis, pancreatitis, renal colic, non-specific abdominal pain, etc.).

This preliminary study has some limitations. First, this study is a questionnaire study based on comments, and therefore, it may not reflect everyday clinical practice. Since most of the questions were attitudinal questions, memory and judgement are not likely to have played a role in how these questions were answered. It was not possible to reach out all EM physicians in Turkey, and we believe that the result would be different if it was possible to reach all physicians out. Other limitations may include the social desirability bias and the central tendency bias of the participants.

\section{Conclusion}

The rates of administration of analgesic drugs by EM physicians to patients with acute abdominal pain are quite low. Whi- 
le no difference was found between attitudes, daily practices of EM specialists, and being employed in state and university hospitals towards the use of analgesics and factors affecting their decision on the use of analgesics, there was a difference between EM residents and EM specialists. EM residents use analgesics much less than EM specialists. EM residents do not implement their decisions on the use of analgesics before the surgeon makes a decision about patient and consents to administer analgesics. There is a need for further studies in which surgeons will be included on this subject.

\section{Acknowledgements}

We would like to thank to Gül Kitapcıoğlu for help assistance in statistical analysis.

\section{Conflict of interest: None declared.}

\section{REFERENCES}

1. Silen W. Cope's Early Diagnosis of the Acute Abdomen. $17^{\text {th }}$ ed. New York, NY: Oxford University Press 1987. p. 5.

2. Boey J The acute abdomen. In: Way L, editor. Current-surgical diagnosis and treatment. 10th ed. Norwalk CT, Appleton and Lange; 1994. p. 441-52.

3. Nissman SA, Kaplan LJ, Mann BD. Critically reappraising the literature-driven practice of analgesia administration for acute abdominal pain in the emergency room prior to surgical evaluation. Am J Surg 2003;185:291-6. CrossRef

4. Thomas SH, Silen W. Effect on diagnostic efficiency of analgesia for undifferentiated abdominal pain. Br J Surg 2003;90:5-9. CrossRef

5. Lee JS, Stiell IG, Wells GA, Elder BR, Vandemheen K, Shapiro S. Adverse outcomes and opioid analgesic administration in acute abdominal pain. Acad Emerg Med 2000;7:980-7. CrossRef

6. LoVecchio F, Oster N, Sturmann K, Nelson LS, Flashner S, Finger R. The use of analgesics in patients with acute abdominal pain.J Emerg Med 1997;15:775-9. CrossRef

7. Pace $S$, Burke TF. Intravenous morphine for early pain relief in patients with acute abdominal pain. Acad Emerg Med 1996;3:1086-92. CrossRef

8. Attard AR, Corlett MJ, Kidner NJ, Leslie AP, Fraser IA. Safety of early pain relief for acute abdominal pain. BMJ 1992;305:554-6. CrossRef
9. Mackway-Jones K, Harrison M. Towards evidence based emergency medicine: best BETS from the Manchester Royal Infirmary. Analgesia and assessment of abdominal pain. J Accid Emerg Med 2000;17:126-9.

10. Brewster GS, Herbert ME, Hoffman JR. Medical myth: Analgesia should not be given to patients with an acute abdomen because it obscures the diagnosis. West J Med 2000;172:209-10. CrossRef

11. Zoltie N, Cust MP. Analgesia in the acute abdomen. Ann R Coll Surg Engl 1986;68:209-10.

12. Howell JM, Eddy OL, Lukens TW, Thiessen ME, Weingart SD, Decker WW; American College of Emergency Physicians. Clinical policy: Critical issues in the evaluation and management of emergency department patients with suspected appendicitis. Ann Emerg Med 2010;55:71-116.

13. Manterola C, VialM, Moraga J, Astudillo P. Analgesia in patients with acute abdominal pain. Cochrane Database Syst Rev. 2011;1:CD005660.

14. Silen W. Cope's early diagnosis of the acute abdomen. $20^{\text {th }}$ ed. New York: Oxford University Press 2000.

15. Kiyan S, Kitapcioglu G, Aksay E, Ersel M, Ozsarac M, Yuruktumen A. Views of Emergency Physicians Working at University Hospitals in Turkey Regarding Use of Analgesics in Patients with Acute Abdominal Pain and Factors Affecting the Use Of Analgesics. Balkan Medical Journal 2011;28:173-8.

16. Wolfe JM, Lein DY, Lenkoski K, Smithline HA. Analgesic administration to patients with an acute abdomen: a survey of emergency medicine physicians. Am J Emerg Med 2000;18:250-3. CrossRef

17. http://www.saglik.gov.tr/TR/belge/1-555/hasta-haklari-yonetmeligi. html.

18. Graber MA, Ely JW, Clarke S, Kurtz S, Weir R. Informed consent and general surgeons' attitudes toward the use of pain medication in the acute abdomen. Am J Emerg Med 1999;17:113-6. CrossRef

19. Kim MK, Galustyan S, Sato TT, Bergholte J, Hennes HM. Analgesia for children with acute abdominal pain: a survey of pediatric emergency physicians and pediatric surgeons. Pediatrics 2003;112:1122-6. CrossRef

20. Hashikawa C, Burke TF, Pallin DJ, Briggs-Malonson M. Analgesia administration for acute abdominal pain: a survey of emergency physicians. Ann Emerg Med 2007;50:91-2. CrossRef

21. Goldman RD, Narula N, Klein-Kremer A, Finkelstein Y, Rogovik AL. Predictors for opioid analgesia administration in children with abdominal pain presenting to the emergency department. Clin J Pain 2008;24:11-5.

22. Rupp T, Delaney KA. Inadequate analgesia in emergency medicine. Ann Emerg Med 2004;43:494-503. CrossRef

23. Todd KH, Deaton C, D’Adamo AP, Goe L. Ethnicity and analgesic practice. Ann Emerg Med 2000;35:11-6. CrossRef 


\section{ORİIINAL ÇALIŞMA - ÖZET}

\section{Türkiye'de üniversite ve eğitim araştırma hastanelerinde çalışan acil tıp hekimlerinin akut karın ağrısında analjezik kullanım sıklığı ve bunu etkileyen faktörler}

\section{Dr. Özgür Özen, Dr. Selahattin Kıyan}

Ege Üniversitesi Tıp Fakültesi Hastanesi, Acil Tıp Anabilim Dalı, İzmir

AMAÇ: Türkiye'de çalışan acil tıp uzman, asistan ve öğretim üyelerinin akut karın ağrılı hastalarda analjezik kullanımı konusundaki tutumları, günlük pratik uygulamaları ve analjezik kullanım kararını etkileyen faktörleri belirlemektir.

GEREÇ VE YÖNTEM: Kesitsel analitik çalışma I5 Kasım 20।3-25 Ocak 20।4 tarihleri arasında Türkiye'deki üniversite hastaneleri, Sağıı Bakanlığı eğitim ve araştırma hastaneleri, devlet hastaneleri ve özel hastanelerde çalışan acil tıp hekimlerine anket formu uygulanarak yapıldı.

BULGULAR: Internet bağlantısıyla $(n=410)$ ve posta $(n=393)$ yoluyla toplam 803 anket dolduruldu (Katılım oranı: \%47). Katılımcıların \%59.3'ü ( $n=470)$ araştırma görevlisi, \%35. I'i $(n=278)$ acil tıp uzmanı ve \%5.7'si ( $n=45)$ öğretim üyesiydi. Katılımcıların analjezik ilaçların; fizik muayene bulgularını \%49.5'i “baskıladığını”, \%34.5'inin “sıklıkla” kullandığı, \%50.7'sinin “muayene ve hastanın planlaması yapıldıktan sonra” uyguladığını, \%60.6'sının “cerrah hastayı görmeden”, \%56.9'unun da “kesin tanı konmadan önce uyguladığını” bildirdi. Hastaların \%47.9'unun "her zaman”, \%4I.6'sının “sıklıkla” analjezik talep ettiklerini bildirdiler. Cerrahi konsültan hekiminin \%34.6'sı "nadiren”, \%28.7'si "hiçbir zaman” analjezik kullanımını önermediği ve cerrahi bölümlerle oluşturulmuş ortak politika olmadığı (\%79.I) yanıtını verdiler. Acil tıp uzmanlarının (devlet ve üniversite) analjezik kullanımı ve hastaya ait faktörler konusunda istatistiksel olarak fark yoktu. Acil tıp uzmanları ve asistanları arasında ise, asistanların "hiçbir zaman” analjezik kullanmam diyen grubu, uzmanlara göre fazlaydı ( $(=0.002)$, asistanlar "operasyon kararı verildiğinde", uzmanlar ise "muayene ve hasta yönetim planı yapıldıktan sonra" analjezik uyguladıklarını ( $\mathrm{p}=0.02 \mathrm{I})$, asistanlar analjeziklerin fizik muayene bulgularını "baskıladığını", uzmanlar ise "netleştirdiğini” ( $\mathrm{p}<0.000 \mathrm{I})$, asistanlar "cerrah muayene etmeden analjezik uygulamadıkları", uzmanlarsa uyguladıklarını bildirdi $(p=0.000 \mathrm{I})$. Hem asistanların hem de uzmanların en sık narkotik analjezik kullandıkları, NSAID kullanım oranlarının her iki grup içinde yüksek olduğu görüldü. Asistanlar ağrı şiddeti, fizik muayene bulguları, inceleme sonuçları ve farklı tanılarda analjezik kullanımı konusunda da uzmanlara göre istatistiksel olarak anlamlı oranda kararsız kalmaktaydı.

Devlette çalışan asistanların analjezikleri “hiçbir zaman” ve "nadiren” kullanırım diyen grubu, üniversitede çalışanlara göre fazlaydı ( $p=0.00$ I). Her iki grupta analjezik kullanımının fizik muayene bulgularına \%57 oranında baskılar yanıtını verdiler. Kıdemli asistanlar (>24 ay) analjeziği kıdemsizlere göre "sıklıkla" uyguladıklarını $(p=0.034)$ ve kıdemsiz asistanların daha çok oranda analjezik kullanımının "fizik muayene bulgularını baskıladığını" inandıklarını bildirdiler $(p=0.002)$.

TARTIŞMA: Acil tıp hekimlerinin akut karın ağrılı hastalarda analjezik kullanım oranları çok düşüktür ve yıllar içerisinde değişiklik olmamıştır. Acil tıp asistanlarının uzmanlarına oranla analjezik kullanım oranları çok daha düşüktür ve analjeziklerin fizik muayeneyi baskıladığına, cerrah hastayı muayene etmeden uygulamaması gerekliliğine inançları yüksektir. Asistanların, analjezik uygulama zamanı daha geçtir. Asistanın kıdemi arttıkça kullanım oranı ve fizik muayene etkilemediği görüşü artmaktadır.

Anahtar sözcükler: Abdominal ağrı; analjezikler; acil hekimleri; anket.

Ulus Travma Acil Cerrahi Derg 2016;22(2):I75-183 doi: 10.5505/tjtes.2015.06706 